\title{
Chromosome differentiation patterns during cichlid fish evolution
}

Andréia B Poletto', Irani A Ferreira', Diogo C Cabral-de-Mello', Rafael T Nakajima', Juliana Mazzuchelli', Heraldo B Ribeiro', Paulo C Venere ${ }^{2}$, Mauro Nirchio ${ }^{3}$, Thomas D Kocher ${ }^{4}$ and Cesar Martins ${ }^{1 *}$

\section{Correction}

After the publication of our work [1], we detected that one of the species analyzed in the study, Astatotilapia latifasciata (Figure 1), was erroneously identified as Haplochromis obliquidens. This species was described as Haplochromis latifasciatus [2] and later ascribed to the genus Astatotilapia [3]. Our mistake comes from the fact that this species is also frequently listed as Haplochromis "zebra obliquidens" in the aquarium trade. Astatotilapia latifasciata has been reported to occur in Lake Nawampasa a small satellite lake of the much larger Lake Kyoga, and in Lake Kyoga located north of Lake Victoria in Uganda [3].

\begin{abstract}
Author details
${ }^{1}$ UNESP - Universidade Estadual Paulista, Instituto de Biociências, Departamento de Morfologia, Botucatu, SP, Brazil. ${ }^{2}$ UFMT - Universidade Federal de Mato Grosso, Instituto Universitário do Araguaia, Pontal do Araguaia, MT, Brazil. ${ }^{3}$ Universidad de Oriente, Escuela de Ciencias Aplicadas del Mar, Boca de Rio, Venezuela. ${ }^{4}$ University of Maryland, Department of Biology, College Park, MD 20742 USA.
\end{abstract}

Received: 7 January 2012 Accepted: 19 January 2012

Published: 19 January 2012

\section{References}

1. Poletto AB, Ferreira IA, Cabral-de-Mello DC, Nakajima RT, Mazzuchelli J, Ribeiro HB, Venere PC, Nirchio M, Kocher TD, Martins C: Chromosome

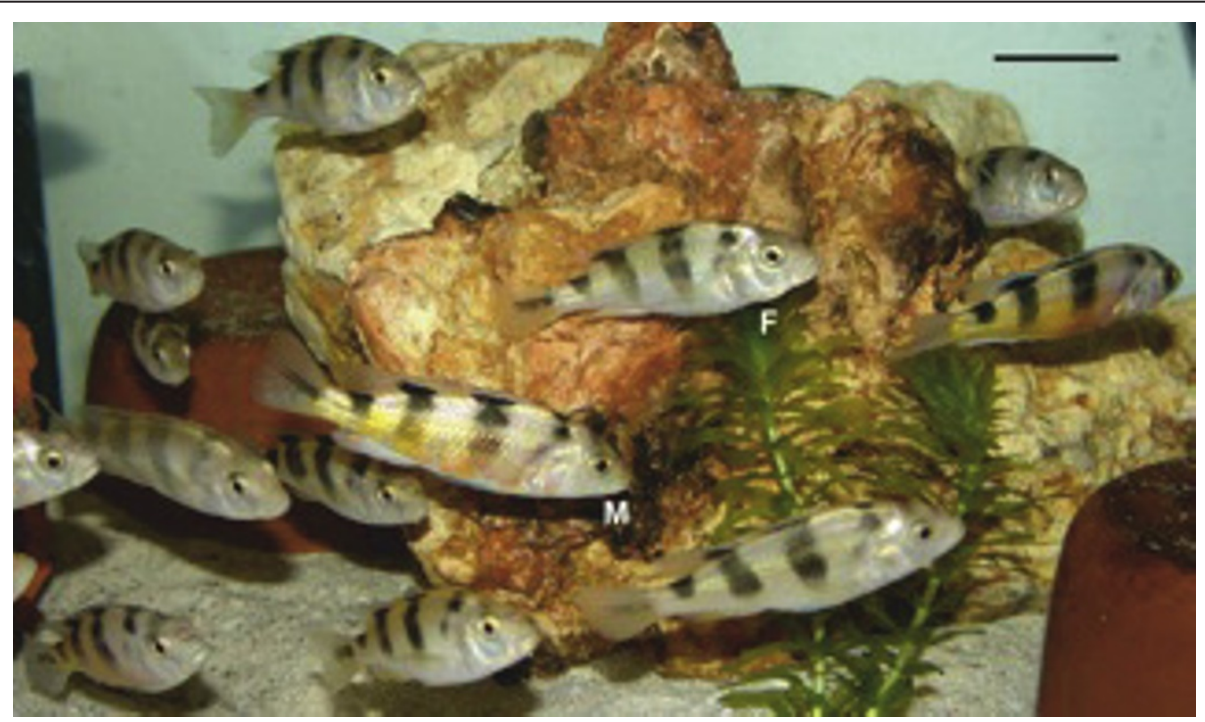

Figure 1 Specimens of Astatotilapia latifasciata. M, male; F, female. Scale bar, $3 \mathrm{~cm}$.

\footnotetext{
* Correspondence: cmartins@ibb.unesp.br

'UNESP - Universidade Estadual Paulista, Instituto de Biociências,

Departamento de Morfologia, Botucatu, SP, Brazil

Full list of author information is available at the end of the article
} 
differentiation patterns during cichlid fish evolution. BMC Genetics 2010,

11:50.

2. Regan CT: New cichlid fishes from lakes Victoria, Kyoga, and Albert. Ann Mag Nat Hist 1929, 10:388-392.

3. Greenwood PH: Towards a phyletic classification of the 'genus' Haplochromis (Pisces, Cichlidae) and related taxa. Part II; the species from Lakes Victoria, Nabugabo, Edward, George and Kivu. Zoology Series 1980, 39(1):1-102.

doi:10.1186/1471-2156-13-2

Cite this article as: Poletto et al: Chromosome differentiation patterns during cichlid fish evolution. BMC Genetics 2012 13:2.

Submit your next manuscript to BioMed Central and take full advantage of:

- Convenient online submission

- Thorough peer review

- No space constraints or color figure charges

- Immediate publication on acceptance

- Inclusion in PubMed, CAS, Scopus and Google Scholar

- Research which is freely available for redistribution

Submit your manuscript at www.biomedcentral.com/submit
() Biomed Central 